\title{
Constitutional Limitations on the War Power
}

I

N SEVERAL articles the writer has discussed the legal limitations on the use of military force by the governor of a state in time of riot and disorder. ${ }^{1}$ It is therein pointed out that the states have no war power, but only authority to use the militia under the law to conserve the peace. The scope of the war power of the federal government is much wider and must include the authorization and exercise by the proper departments of such constraint and control over all persons and property as the successful prosecution of war may require.

The lawyer is the natural defender of constitutional government and civil liberty. In this critical period he must face the question how far the safeguards of right and justice to the individual which are embodied in the Bill of Rights may have to be suspended or qualified by the requirements of public defense. As Professor Freund has pointed out, "Popular right is no longer identified with individual right but rather with common public interest." Indifference is the dominant attitude toward the guaranties of the Bill of Rights, such as security against unreasonable searches and seizures, freedom of speech, or of the press, the right of peaceable assembly, the right to fair trial by jury in the ordinary courts before one can be punished, and due process of law. There is much greater interest in cutting these down where they are inconvenient obstacles in

I A discussion of the authorities dealing with the limits on the exercise of military power over the citizen will be found in the following articles by the writer: Military Dictatorship, 1 California Law Review, 413; Martial Law, 12 Columbia Law Review, 529; Unconstitutional Claims of Military Authority, 24 Yale Law Journal, 189; 5 Journal Criminal Law and Criminology, 718; Qualified Martial Law, 14 Michigan Law Review, 102, 197; Effect of War, 24 Case and Comment, 3. See also W. W. Grant, Suspension of Habeas Corpus in Strikes, 3 Virginia Law Review, 249; H. M. Bowman, Martial Law and the English Constitution, 15 Michigan Law Review, 93; Willoughby, The Constitution, chapters 1xi, lxii; compare the article on The Need, Propriety and Basis of Martial Law, by George S. Wallace, 8 Journal Criminal Law and Criminology, 406, in which he presents the extreme West Virginia doctrine of unlimited military authority.

2 Standards of American Legislation, pp. 151, 177, 183. 
the enforcement of governmental policies than in preserving them intact, and in fact this seems to be regarded as a patriotic duty.

While it may be true that we cannot have free democracy and successful war at the same moment, let us not throw overboard more ballast than is necessary to weather the storm. The true duty of constitutional interpretation will be to reconcile, so far as possible, public power with individual liberty, the safeguards of justice with the practical necessities of war. Some of these clauses, the inheritance of former centuries, are fairly general and elastic and will yield easily to restrictions, because of their indefiniteness. Freedom of speech does not permit a man to say what is injurious to public or private rights, and the usual latitude of discussion has already been curtailed.' Only unreasonable searches and seizures are forbidden. The guaranties of jury trial and regular procedure in criminal cases are, however, specific.

The fifth amendment provides for indictment by a grand jury "except in cases arising in the land or naval forces, or in the militia, when in actual service in time of war or public danger." This is evidently not a mere peace provision." The sixth amendment provides that in all criminal prosecutions the accused shall enjoy the right to a speedy and public trial, by an impartial jury of the state and district wherein the crime shall have been committed.

Can these amendments be ignored or suspended by a proclamation of martial law by executive order or legislative act as to any class of our citizens? The Constitution itself provides when the privilege of the writ of habeas corpus may be suspended, and it apparently did not intend to authorize the suspension of the other guaranties by implication. ${ }^{\circ}$ It must be remembered, moreover, that the weaker and more unpopular an accused person or class of persons may be, the greater is the need of orderly procedure to ascertain and protect their rights against the whirlwind of popular wrath and suspicion. The Palladium

3 Trading with the Enemy Act of October 6, 1917, \& 19. See Constitutional Protection of the Right of Freedom of Speech and of the Press, 17 Columbia Law Review, 622 .

4 Wambaugh, 30 Harvard Law Review, 663.

- Art. I, \& 9, subd. 2. 
of liberty must be intended for times of stress, if it is the genuine article.

Mr. Henry A. Forster, of the New York Bar, has written a communication published in the September number of the California Law Review ${ }^{6}$ in which he advances the following propositions :

"During a national war with any first class power, the Federal Constitution does not inure to the benefit of the public enemy, of spies, or of enemy sympathizers, whether native or foreign. All spies should be forthwith tried by court-martial and, if convicted, shot. Enemy sympathizers, after conviction by court-martial, should be either confined at hard labor during the war, or else should be deported to the enemy country."

It is perfectly plain that the Constitution does not limit the war power in dealing with the public enemy, ${ }^{7}$ but it is an entirely different question whether it limits the executive or legislative power in dealing with citizens accused or suspected of acts of disloyalty. Mr. Forster apparently sees no distinction between powers over citizens and powers over the public enemy; or at least would seem to believe that an accusation that a citizen is an enemy sympathizer will at once give him the status of a public enemy without constitutional rights. He sees no distinction between persons with a military status, subject to military law, and civilians who may be accused of crimes involving disloyalty.

As far as American authorities go, the prosecution and punishment of citizens suspected of conspiracy, sedition, disloyal practices, and of treason itself, on loyal territory in time of war, belong solely to the tribunals of the law and not to military commissions or courts-martial. ${ }^{8}$ The exercise of martial law over

6 Vol. 5, p. 407. This is the same proposition which he has published as a part of a report of a New York State Bar Association Committee on the duty of courts to refuse to execute statutes in contravention of the fundamental $\mathrm{law}$, pages 23 to 24 . The communication to the California Law Review omits, however, a statement made in that report, "In time of war, the laws are silent; during war, civil rights may be suspended at the will of the commander-in-chief."

${ }^{2}$ Dow v. Johnson (1880), 100 U. S. 158, 25 L. Ed. 632; New Orleans v. N. Y. Mail S. S. Co. (1874), 20 Wall. 387,22 L. Ed. 354.

${ }^{8}$ Ex Parte Milligan (1866), 4 Wall. 2, 8 L. Ed. 281; Johnson v. Jones (1867), 44 Ill. 142; In re Kemp (1863), 16 Wis. 382; Smith v. Shaw (1815), 12 Johns. 257; Griffin v. Wilcox (1863), 21 Ind. 370; Johnson v. Duncan (1815), 3 Martin (La.) 530, 6 Am. Dec. 675; Hare, American Constitutional Law, chapter 44. 
citizens is restricted to those places which are the theatre of war and to their immediate vicinity. ${ }^{9}$

Mr. Forster does not specify whether legislative authority would be required for the imprisonment or deportation of citizens accused of being disloyal in their sympathies, but from his reference to the Vallandigham case it may be inferred that he considers that military orders would be sufficient. Neither does he indicate whether he would include all pro-German, pacificists, socialists and members of the I. W. W. in the class of enemy sympathizers subject to court-martial; or how he would decide the question. It is Mr. Foster's argument that because "militaristic fuedalism" asserts that no free people have any rights which feudalism is bound to respect, therefore American citizens have no private rights or individual liberty which democratic government is bound to respect during war. He assumes that constitutional safeguards are intended to protect the guilty rather than those unjustly accused, and the public defense is only possible by the abrogation of all individual rights and the suspension of safeguards intended to secure the essential principles of justice.

Mr. Forster's attempt to distinguish the Milligan case ${ }^{10}$ is entirely mistaken. $\mathrm{He}$ asserts that the only question actually decided was the legal question whether a federal statute of 1863 gave authority for military courts to punish for disloyal practices in pacific districts, such as Indiana, and that no constitutional question was involved. But, as David Dudley Field, attorney for Milligan, pointed out in his great argument in that case, "It is not a question of how far the legislative department can deal with the question of martial rule. Whatever has been done in these cases has been done by the executive department alone." The military commission depends entirely upon the executive will for its creation. It is held by the Supreme Court that martial law and military trials of civilians could not exist in a state not invaded and not engaged in rebellion in which the civil courts were open, and that the constitutional guaranties could not be suspended by executive proclamation. There is a dictum of the majority that the result would have been the 
same, even if there had been an act of Congress authorizing military trials, and that Congress is limited by the Constitution in time of war as in time of peace. The minority, however, dissented from this dictum.

In a letter to me, dated March 1st, 1916, Mr. Forster wrote: "In the event of foreign complications, if we did not declare martial law at once, how many railroad bridges, railroad tunnels, aqueducts, munition. works and factories capable of becoming munition works, would survive the first month of friction?" Mr. Forster has proved to be a false prophet in regard to the necessity for martial law, and he does not advance any convincing reasons why one should now believe that arbitrary executive power over the citizen is the only alternative to the triumph of our enemies. Are espionage and sabotage so rampant that our prisons should be kept full of pacificists and pro-Germans, held indefinitely at hard labor upon the order of military officers, for offenses not recognized by law? No portion of American territory is within the theatre of actual warfare, nor is it threatened with invasion, and no occasion has yet arisen for military trials of civilians or any other conflict with constitutional provisions.

There is no doubt that upon the theater of actual military operations in war, supreme military power over the citizen is demanded by military necessity. This is due process of law. A different question, however, arises in places outside the actual theater of war. The Honorable Charles E. Hughes, in his recent address before the American Bar Association, concedes the right of the citizen to normal judicial procedure so long as, in a true sense, the administration of justice remains unobstructed, although he asserts that the fifth and sixth amendments may not always have complete and universal application in time of threatened invasion or great emergency.

Military power may certainly prevent traitors and spies from accomplishing their intended mischief by the use of force, and may restrain those who interfere directly with military efforts or with the safety of the forces. Such is the effect of the decision in Moyer v. Peabody ${ }^{11}$ on preventive arrest and detention. Whether military officers have authority to arrest and punish

11 (1909), 212 U. S. 78, 53 L. Ed. 410, 29 Sup. Ct. Rep. 235. See also Luther v. Borden (1849), 7 How. 1, 12 L. Ed. 581. 
citizens accused of espionage and sedition, or whether the constitutional provisions do not insure them, when accused, a speedy and public trial by jury, is a question not yet clearly decided. ${ }^{12}$

Section 1343 of Revised Statutes of the United States provides that "All persons who in time of war or rebellion shall be found lurking or acting as spies in or about any of the fortifications, posts, quarters, or encampments of any of the armies of the United States, or elsewhere, shall be triable by a general courtmartial, or by a military commission, and shall, on conviction thereof suffer death." This statute may be upheld as dealing with those who may be regarded as public enemies. ${ }^{13}$

The extraordinary authority over alien enemies given the President by the Act of $1798,{ }^{14}$ when war is declared, now being exercised by President Wilson, does not authorize alien enemies to be executed summarily as spies, but only to be removed, arrested, interned, and regulated by executive order, as public safety may require. The practice of other governments may be taken as indicating that such authority is due process of law. ${ }^{15}$

It has been suggested in Miller v. United States ${ }^{16}$ (a case relating to the confiscation of enemy property) that, in case of a foreigu war, not only the inhabitants of the enemy's country are enemies, but adherents and abettors of the enemy may be so regarded, although not resident in hostile territory. Pomeroy, in his Constitutional $\mathrm{Law}^{17}$ admits the possibility that military arrests, trials, and punishments may be employed against civilians suspected of disloyal practices, as a species of hostilities directed against those who have placed themselves in the position of public enemies, and have so deprived themselves of the safeguards which the Constitution throws about the lives, liberty and property of citizens generally. That such an exception in regard to war power is to be implied in the Bill of Rights has never been decided, as the intimation in the Miller case is mere dictum. ${ }^{18}$

12 Smith v. Straw (1815), 12 Johns. 25\%. See 24 Case and Comment, 3.

1316 Op. Atty. Gen. 294; Ex Parte Wildman (1876), Fed. Cas. No. 17, 653a. Matter of Martin (1865), 45 Barb. (N. Y.) 142; Jones v. Seward (1863), 40 Barb. 563, 41 Barb. 269.

I+ U. S. Rev. Stats. \& 4067, 1913 Comp. Stats. § 7615.

10 See Lockington v. Smith (1817), Fed. Cas. No. 8448.

16 (1870), 11 Wall. 268, 310, 318.

$17 \S \S 708-711$.

18 See Hare, American Constitutional Law, pp. 925, 927, 963. 
Mr. Justice Field expressed very strongly the opinion that the power of the government to carry on war would not be crippled nor its efficiency impaired, if it is prohibited from authorizing the arrest of persons on suspicion of disloyalty or complicity with the enemy, without examination or trial. $\mathrm{He}$ vigorously denied that in loyal states constitutional guaranties may be suspended. ${ }^{19}$ While these expressions were used in dissenting opinions, the Supreme Court has never repudiated the premises upon which his arguments were based.

In Zadig's case $^{20}$ the House of Lords upheld a most sweeping exercise of power under the Defense of the Realm Act. The question was whether interning a naturalized citizen of German birth by executive order was authorized by the Act. The only question here was one of statutory construction, but there was a vigorous dissent by Lord Shaw on the ground that the statute ought not to be construed in favor of permitting a breach of the fundamental constitutional rights which are protective of British liberty.

The power to intern citizens, when their activities or hostile associations may have exposed them to suspicion, is different from the power to prosecute and punish for crime, and may not be subject to the fifth and sixth amendments. The question of the validity of such legislation, however, would be different in the United States - than before the English House of Lords, and it would have to be decided whether it transcended the constitutional guarantees of the liberty of the citizen, and whether it was a due exercise of governmental power.

Although we are in competition with a barbarous and ferocious autocracy, the most terrible military power in the world, we may still remain a free country and preserve the principles of constitutional government, such as the supremacy of law, which we have inherited. Our country will not be impotent in the face of war nor the energies of the republic paralyzed, if we proceed against citizens in a legal and orderly manner. Constitutional safeguards are intended to protect not the guilty, but the innocent.

19 Beckwith v. Bean (1878), 98 U. S. 266, 293, 298, 25 L. Ed. 124; Mitchell v. Clark (1883), 110 Ư. S. 633, 648, 28 L. Ed. 279, 4 Sup. Ct. Rep. 170.

20 Rex v. Halliday (1917), App. Cas. 260. 
The power to intern citizens upon suspicion, when their activities or hostile associations may have exposed them to suspicion, is different in its nature and exercise from the power to prosecute and punish for crime, and the provisions as to indictment and jury trial would not seem to apply. The question of the existence of such authority, however, would not be a mere matter of statutory construction as in the English House of Lords, but it would have to be decided whether such measures transcended the constitutional guaranties of the rights of the citizen, and whether they are a due exercise of governmental power.

Congress has vast and extraordinary powers of interual regulation in exerting to the full the energy and resources of the nation in war and curbing dangerous agitation and domestic hostility. Whatever legislation is necessary to prevent assistance being given the enemy from within may be found to be constitutional on some theory of construction other than that of suspension of the Bill of Rights. Legislation has already been enacted, controlling the leading industries of the country, providing for the regulation of prices of commodities necessary for national defence, and restricting the publication of hostile newspapers. We may have to go much further and enact measures prohibiting hoarding and providing for the compulsory sale of all necessaries of life, such as food, fuel and drugs at a reasonable price. In Mr. Hughes' language: "Congress has the power to enact whatever legislation is necessary to prosecute the war with vigor and success." This grant of power, however, would not call for the substitution of courts-martial for criminal prosecution of civilian offenders in the regular courts. It will hardly be claimed that private property may be taken for public use without just compensation, but freedom of the press, of speech, of contract and of movement may be subjected to due regulations, called for by the needs of public defence.

Mr. Thomas W. Gregory, attorney general of the United States, has expressed the opinion that the federal government can find in existing statutes, and others now pending before Congress, power to handle any situation likely to arise because of the ill-advised activities of disloyal agitators, who from good or bad motives seek to hamper our work in the war.

University of Illinois. Henry Winthrop Ballantine. 